\title{
Dialog z interesariuszami środowiskowymi w projektowaniu wizji i reformy szkolnictwa wyższego w Polsce (2013-2015)
}

\begin{abstract}
STRESZCZENIE. W relacji pomiędzy państwem a interesariuszami interesujące jest zwłaszcza to, z jakim przyjęciem spotyka się projektowana i wdrażana reforma, jakie grupy ją popierają, a jakie się jej sprzeciwiają, zaś w przypadku sprzeciwu - co jest osią owej niezgody. Przedmiotem prezentowanych w artykule rozważań w odniesieniu do reformowania szkolnictwa wyższego w Polsce jest niezgodność wartości przyjmowanych przez interesariuszy wewnętrznych - część kadry akademickiej z wartościami preferowanymi przez interesariuszy zewnętrznych, czyli państwo. Artykuł dotyczy przede wszystkim stanowisk i działań grup interesariuszy środowiskowych sprzeciwiających się forsowanemu przez Ministrestwo Nauki i Szkolnictwa Wyższego nurtowi reformowania szkolnictwa wyższego w Polsce i/lub proponujących własną wizję zmian w szkolnictwie wyższym i nauce w latach 2013-2015, tj. Konferencji Rektorów Akademickich Szkół Polskich, Obywateli Nauki oraz Komitetu Kryzysowego Humanistyki Polskiej. Odniesienie się w tekście do reakcji ministerstwa na te działania pozwala również wyciągnąć wnioski na temat natury społecznego dialogu interesariuszy środowiskowych z ministerstwem i stopnia partycypacji środowiska w procesie reformowania szkolnictwa wyższego w Polsce.
\end{abstract}

SŁOWA KLUCZOWE: reforma szkolnictwa wyższego, polityka szkolnictwa wyższego, uniwersytet, interesariusze, dialog społeczny

\section{Wprowadzenie}

Czołowy badacz szkolnictwa wyższego okresu PRL Jan Szczepański (1999: 20-21), pisząc o mechanizmach reformowania i czynnikach decydujących o powodzeniu reform, podkreślał znaczenie działalności wszelkich grup zaangażowanych w proces m.in. przygotowania czy modyfikowania reformy oraz znaczenie specjalistycznej wiedzy nie tylko o działaniu reformatora, ale także o tym, do kogo reforma jest 
adresowana, z jakim spotyka się przyjęciem, jakie grupy (i jak silne) ją popierają, a jakie się jej sprzeciwiają (Dziedziczak-Foltyn 2009). Dlatego tak istotnym dla analiz procesów reformowania szkolnictwa wyższego jest przyjrzenie się kwestii funkcjonowania owych grup poparcia lub sprzeciwu, jak również ich zaistnienia w debacie publicznej w Polsce.

W odniesieniu do tego rodzaju ugrupowań przyjęte zostało określenie „interesariusze" (stakeholders), które zgodnie z opisywanym przez Guya Neave’a (2002: 18) podejściem anglosaskim dotyczy zarówno interesariuszy wewnętrznych, jak i zewnętrznych. Osobno wskazywaną kategorią jest państwo reprezentowane przez ministerstwo odpowiedzialne za szkolnictwo wyższe (Neave 2002: 25), zaliczane do interesariuszy zewnętrznych (Bjørkquist 2011). Wspomniane grupy poparcia lub sprzeciwu to interesariusze środowiskowi, gdyż właśnie te grupy wpisują się w definicję interesariuszy wewnętrznych obejmujących nauczycieli akademickich, naukowców, pracowników administracyjnych i studentów, dla odróżnienia od interesariuszy zewnętrznych, do których można zaliczyć wszystkich uczestników życia publicznego i grupy interesu, którzy są zainteresowani szkolnictwem wyższym, czyli najczęściej pracodawców i usługodawców oraz rodziców studentów (Musiał 2013: 190). I choć Catharina Bjørkquist (2011) zalicza akademików do reżimu ekspertów (expert regime)1, jako interesariuszy wewnętrznych mających wpływ na uczelnie poprzez możliwość głosowania w procesach podejmowania decyzji, to w niniejszym artykule kategoria interesariuszy wewnętrznych nie odnosi się jedynie do dzierżących lokalnie (w ramach danej uczelni) władzę profesorów, a do szeroko pojętej kadry akademickiej, traktowanej jako zróżnicowana zbiorowość w systemie szkolnictwa wyższego.

W Polsce kadra akademicka (licząca ok. 100 tys. osób) oraz państwo nie zgadzają się w kwestii oczekiwań wobec szkolnictwa wyższego, co tworzy swoiste pole konfliktowe pomiędzy tymi interesariuszami szkolnictwa wyższego (Kwiek 2010: 86-87). Kadra, na której opiera się cały system kształcenia i badań, musi się bowiem najbardziej dostosowywać do przemian uniwersytetu, w tym godzenia fundamentalnych wartości akademickich opartych na tradycyjnej misji uniwersytetu z wymogami transformacji sektora w celu budowania gospodarki opartej na wiedzy, zorientowanej bardziej pragmatycznie. Konflikt zachodzi zatem między opartą na modelu instytucjonalnym wizją uniwersytetu podzielaną przez „wspólnotę badaczy" a wizją reformatorów i decydentów politycznych, której podstawę stanowi instrumentalny model uniwersytetu kształtowanego przez zewnętrzne otoczenie i zewnętrznych interesariuszy (Kwiek 2012: 92). Problem w tym, że kadra akademicka jest „całkowicie nieświadoma szerszych procesów transformujących ich systemy edukacyjne i ich instytucje” i może mieć kłopot z akceptacją zmian

${ }^{1}$ Dla odróżnienia od reżimu dobrobytu (welfare regime), negocjacyjnego (bargaining regime) i przedsiębiorczego (entrepreneurial regime). 
dokonywanych w duchu instrumentalnym (Kwiek 2010: 127). Można w Polsce dostrzec rozbieżność pomiędzy konkurencyjnymi dyskursami dotyczącymi przyszłości uniwersytetów i zróżnicowania ich misji, która przybiera postać „zmagań” między reformatorami a wspólnotą akademicką (Kwiek 2013). Tymczasem na Zachodzie wskazywana jest potrzeba takiego procesu dyskusji i negocjacji idei między decydentami a akademikami, który przełoży się na tworzenie polityki szkolnictwa wyższego (Newman, Couturier i Scurry 2004: 46).

Uproszczeniem byłoby sprowadzenie tego, co dzieje się obecnie w debacie publicznej w kwestii roli uniwersytetów, do prostej opozycji: postępowe ministerstwo vs. konserwatywne ugrupowania interesariuszy środowiskowych broniących swego status quo. Przedmiotem rozważań będzie jednak niezgodność wartości przyjmowanych przez interesariuszy wewnętrznych - część owej kadry a tymi podzielanymi przez interesariuszy zewnętrznych - państwo/ministerstwo. Można bowiem przyjąc, że obie strony w tym sporze reprezentują dwa odrębne rodzaje dyskursów dotyczących uniwersytetów, które można nazwać idealistyczno-humanistycznym oraz pragmatyczno-rynkowym (Dziedziczak-Foltyn 2014). Artykuł dotyczy zatem stanowisk i działań grup sprzeciwiających się forsowanemu przez Ministerstwo Nauki i Szkolnictwa Wyższego nurtowi reformowania szkolnictwa wyższego w Polsce i/lub proponujących własną wizję zmian w szkolnictwie wyższym i nauce. Zaproponowana w tekście analiza koncentruje się na latach 2013-2015, czyli okresie ostatnich zmian w ustawie Prawo o szkolnictwie wyższym z 2014 r., jak również okresie, w którym powstały dwa ugrupowania przedstawicieli środowiska akademickiego wypowiadające się w sprawie reformy: Obywatele Nauki (jesień 2012) oraz Komitet Kryzysowy Humanistyki Polskiej (zima 2013/2014). W przypadku Konferencji Rektorów Akademickich Szkół Polskich analiza sięga kilku lat wcześniej ze względu na wieloletnie zaangażowanie tej organizacji w ocenę planowanych przez MNiSW zmian prawnych w systemie szkolnictwa wyższego i nauki oraz przygotowanie dwóch projektów dokumentów strategicznych dotyczących szkolnictwa wyższego. Intencją autorki jest nie tylko dokonanie bilansu trzyletniego okresu debaty publicznej dotyczącej reformowania szkolnictwa wyższego w Polsce, obejmującego analizę treści wiodących postulatów owych reprezentantów środowiska akademickiego (interesariuszy środowiskowych), zawartych w ogólnodostępnych dokumentach i materiałach informacyjnych, ale również analiza treści sprawozdań z debat, w tym medialnych interpretacji działań podejmowanych przez debatujące strony, pozwalająca określić relacje poszczególnych organizacji z ministerstwem. Analiza stanowisk w tej dyskusji, jak i charakteru wydarzeń, które im towarzyszą (debaty, konferencje, spotkania, „wykłady okupacyjne” czy marsze), jest doskonałą okazją do tego, aby pokazać jakość debaty i zastanowić się, na ile możliwy jest dialog pomiędzy MNiSW a trzema podmiotami, które próbują - z różnym skutkiem - włączyć się w projektowanie reformy szkolnictwa wyższego. 
W związku z tym nasuwa się kilka pytań, na które warto spróbować odpowiedzieć: Czy w Polsce mamy do czynienia z taką debatą publiczną o uniwersytetach, która ma realny wpływ na tworzenie polityki szkolnictwa wyższego? Czy w debacie tej jest miejsce na rzeczywisty dialog pomiędzy debatującymi stronami? Czy debata daje szansę na konstruktywne pogodzenie odmiennych wartości przewodzących różnym kategoriom interesariuszy? Odpowiedzi na te pytania pozwolą stwierdzić, czy jest to debata służąca demokratycznie projektowanym i wprowadzanym zmianom, czy raczej przykład debaty dla debaty, rozumianej w kategoriach działania neopozornego ${ }^{2}$, a więc świadectwa powierzchownej otwartości władz publicznych na głosy interesariuszy wewnętrznych, taktyki obliczonej głównie na tworzenie pozornie prodeliberacyjnego wizerunku ministerstwa.

\section{KRASP - legitymizowany partner środowiskowy ministerstwa}

Powołana w 1997 r. Konferencja Rektorów Akademickich Szkół Polskich, która w 2005 r. zyskała umocowanie ustawowe określające jej prawa i obowiązki, ma na celu reprezentowanie wspólnych interesów uczelni akademickich, w tym stanie na straży tradycyjnych wartości akademickich. Owo umocowanie legislacyjne dotyczące funkcji doradczych i opiniodawczych KRASP pozwala temu podmiotowi prawnemu na występowanie do organów władzy publicznej w istotnych sprawach szkolnictwa wyższego, nauki i kultury, jak również na wyrażanie z własnej inicjatywy opinii i przedstawianie wniosków w sprawach dotyczących szkolnictwa wyższego, nauki i kultury. $Z$ zapisów ustawowych wynikają również obowiązki organów władzy publicznej w zakresie zasięgania opinii KRASP w sprawach m.in.: zasad działania i kierunków rozwoju szkolnictwa wyższego oraz systemu badań naukowych, projektu budżetu państwa w części dotyczącej szkolnictwa wyższego oraz projektów aktów prawnych dotyczących szkolnictwa wyższego, nauki i kultury, a także promocji nauki polskiej za granicą (Prawo o szkolnictwie wyższym, art. 55).

Wiosną 2007 r. w deklaracji w sprawie zasad reformowania polskiej nauki i szkolnictwa wyższego Prezydium KRASP i Prezydium PAN ogłosiły „gotowość do konstruktywnej współpracy z władzami państwowymi w reformowaniu szkolnictwa wyższego i nauki" i zaapelowały o konsultowanie z KRASP i PAN wszelkich projektowanych zmian w obszarze ich działania (KRASP. Deklaracja... 2007). O gotowości do współpracy ze strony KRASP, ale również podejściu do tej współ-

${ }^{2} \mathrm{O}$ działaniach neopozornych w sferze nauki i szkolnictwa wyższego pisze Marek Czyżewski (2009), definiując je, w odróżnieniu od działań pozornych (klasycznego pojęcia socjologicznego), jako nieprzydatne lub wręcz szkodliwe, ale uznawane za jako tako przydatne lub nawet w pełni przydatne ze względu na dominujący dyskurs modernizacyjny i demokratyzacyjny, który nie dopuszcza alternatywnych i sceptycznych punktów widzenia. 
pracy ze strony MNiSW świadczą przede wszystkim losy dwóch dokumentów strategicznych poświęconych przyszłości szkolnictwa wyższego, które KRASP przygotowała w latach 2009 i 2015.

Historia prac nad pierwszym z tych dokumentów sięga $2008 \mathrm{r}$. W uchwale Prezydium KRASP (Dokument $\mathrm{nr}$ 1/V) zaapelowano o podjęcie działań zmierzających do opracowania strategii rozwoju szkolnictwa wyższego w Polsce i zaproponowano, aby przygotowanie takiego dokumentu powierzyć zespołowi działającemu w ramach Fundacji Rektorów Polskich. W 2009 r. Konferencja Rektorów (Dokument $\mathrm{nr} 22 / \mathrm{V}$ ) oficjalnie wysunęła postulat opracowania strategicznego planu przyszłych reform w szkolnictwie wyższym stanowiących element procesu modernizacji kraju, i zapowiedziała przedłożenie rządowi RP oraz społeczeństwu projektu strategii rozwoju szkolnictwa wyższego do 2020 r. W 2010 r. przyjęto „Strategię rozwoju szkolnictwa wyższego 2010-2020 - projekt środowiskowy", uznając go za podstawę przygotowania projektu narodowej strategii rozwoju szkolnictwa wyższego w Polsce oraz zwracając się do rządu RP o niezwłoczne podjęcie prac nad taką strategią (Dokument $\mathrm{nr}$ 36/V). Z racji odwlekania przyjęcia strategii rozwoju szkolnictwa wyższego przez ministerstwo ${ }^{3}$ Konferencja dwukrotnie w swoich uchwałach (Dokument nr 56/V, Dokument nr 1/VI) zwracała się do ministra nauki i szkolnictwa wyższego o przedstawienie strategii rozwoju jako części ponadsektorowej Strategii Rozwoju Kapitału Ludzkiego. Na początku 2013 r. KRASP wraz z Radą Główną Szkolnictwa Wyższego, Konferencją Rektorów Zawodowych Szkół Polskich oraz Fundacją Rektorów Polskich wystosowały Apel do Parlamentu i Rządu Rzeczypospolitej Polskiej, w którym organizacje te złożyły deklarację aktywnego włączenia się w procesy wprowadzania zmian na rzecz przyspieszania rozwoju kraju i wzrostu jego pozycji międzynarodowej. W towarzyszącej apelowi uchwale Prezydium KRASP (Dokument nr 9/VI) zwróciło uwagę, iż nie nastąpiły działania związane z wypracowaniem i przyjęciem zapowiedzianego przez minister Barbarę Kudrycką Programu rozwoju szkolnictwa wyższego, który miał się odwoływać do rządowych horyzontalnych dokumentów strategicznych oraz projektu środowiskowego KRASP. Co więcej, Konferencja Rektorów uznała działania MNiSW, w tym przedłożenie ówczesnego ministerialnego projektu zmian legislacyjnych, za naruszające deklarowane zasady współdziałania między organami rządowymi i reprezentatywnymi gremiami o charakterze społecznym. Wyraziła przy tym przekonanie, że tylko wspólne prace nad wizją rozwoju szkolnictwa wyższego i nauki, a nie komentowanie zmian legislacyjnych w ramach konsultacji społecz-

${ }^{3}$ W latach 2009-2010 zostały opracowane dwa projekty strategii: środowiskowy - przygotowany na zlecenie KRASP przez Fundację Rektorów Polskich oraz ministerialny - przygotowany na zlecenie MNiSW przez Ernst \& Young i Instytut Badań nad Gospodarką Rynkową. Pomimo prac MNiSW nad Programem rozwoju szkolnictwa wyższego do 2020 roku, który miał stanowić kompromis pomiędzy oboma projektami strategii, zapowiadany program nie został przyjęty w ciągu kolejnych pięciu lat (do 30.09.2015 r.). 
nych, przyspieszą proces modernizacji kraju. W załączniku do uchwały wskazano przykłady działań KRASP na rzecz rozwoju systemu szkolnictwa wyższego i nauki po 2005 r., w tym nie tylko dokumenty dotyczące strategii i kierunków rozwoju systemu szkolnictwa wyższego i nauki, ale również oceny planowanych zmian legislacyjnych w systemie (Dziedziczak-Foltyn 2011) oraz konieczności zapewnienia właściwych warunków rozwoju szkolnictwa wyższego, nauki i kultury. Określono też przyszłe działania w kadencji 2012-2016, traktowane jako działania priorytetowe, w tym: „działania wspomagające przyjęcie i wdrożenie strategii rozwoju szkolnictwa wyższego i wynikających z niej projektów legislacyjnych, zmierzających do stworzenia w kraju nowoczesnego, dobrze osadzonego w kontekście międzynarodowym systemu szkolnictwa wyższego" (Dokument nr 9/VI).

W zasygnalizowane powyżej działania wpisuje się historia drugiego dokumentu KRASP, który został przedstawiony ministerstwu w maju 2015 r. Jak wynika ze Sprawozdania z działalności Konferencji Rektorów Akademickich Szkół Polskich za rok 2014, ze względu na szybko postępujące zmiany w otoczeniu systemu szkolnictwa wyższego postanowiono uaktualnić propozycje przedstawione w środowiskowym projekcie strategii i zaprezentować nowe. Z tego powodu w kwietniu 2013 r. KRASP przyjęla ogólną wizję Programu rozwoju szkolnictwa wyższego do 2020 roku, zlecając Fundacji Rektorów Polskich zadania doprecyzowujące ten program, natomiast zasadnicze prace nad programem miały miejsce $\mathrm{w} 2014 \mathrm{r}$. W grudniu 2014 r. gotowe były opracowania składające się na ten dokument, który Prezydium i Zgromadzenie Plenarne KRASP przyjęły w pierwszej połowie 2015 r. (Dokument nr 34/VI, Dokument nr 40/VI). Zgodnie z deklaracją Jerzego Woźnickiego (2015a: 5), redaktora opracowania i autora dwóch części, dokument ten ma stanowić przykład przyjętej w KRASP dobrej praktyki przygotowywania w ramach każdej kadencji „dzieła programowego o charakterze strategicznym”, które potwierdza proreformatorskie i twórcze nastawienie Konferencji Rektorów. Wyrasta on również z chęci zainspirowania społeczności akademickiej do aktywności i angażowania się w sprawy szkolnictwa wyższego i nauki poprzez pogłębiony i skonkretyzowany dialog społeczny w szkolnictwie wyższym i nauce (Woźnicki 2015a: 6).

Zaproponowany przez KRASP Program złożony jest z pięciu opracowań:

- Opis prac nad Programem i jego najważniejsze elementy (red. J. Woźnicki),

- Misja społeczna uniwersytetu w XXI wieku (red. A. Szostek),

- Diagnoza szkolnictwa wyższego (red. J. Górniak),

- Finansowanie szkół wyższych ze środków publicznych (red. J. Wilkin),

- Deregulacja w systemie szkolnictwa wyższego (red. J. Woźnicki).

$\mathrm{Z}$ racji bardzo obszernej formy tego dokumentu (ponad 700 stron) nie sposób w kilku zdaniach go streścić czy choćby wypunktować głównych założeń. Dlatego proponowana tu analiza dotyczy dwóch kwestii natury ogólnej wynikających z dokumentu, a powiązanych z głównymi wątkami poruszanymi w artykule. Pierwszą 
z nich jest misja społeczna uniwersytetu, która realizując się w trzech płaszczyznach aktywności akademickiej: prowadzeniu badań naukowych, kształceniu oraz upowszechnianiu wiedzy i kultury, opisywana jest jako doświadczająca napięć związanych ze zmianami w otoczeniu społeczno-gospodarczym w Polsce i na świecie. Wyzwania te przysparzają uczelni wielu dylematów: wartości akademickie vs. służebność społeczna, autonomia vs. podległość zewnętrznej kontroli, kultura akademicka vs. kultura korporacyjna, rynek pracy vs. formacja obywatelska, elitarność vs. masowość kształcenia. Lista ta nie wyczerpuje problemów, przed którymi stoją uniwersytety, ale syntetyzuje najważniejsze napięcia wynikające ze zmieniającej się roli uniwersytetu we współczesnym świecie. Wskazane alternatywy nie oznaczają przy tym konieczności wyboru jednej z opcji, pokazują raczej potrzebę namysłu nad każdą z nich i drogę do wypracowania konsensusu. Autorzy Programu za najważniejsze kierunki rozwiązań dylematów uniwersytetu uznali takie, które próbują łączyć zalety każdego z podejść w ramach wspomnianych pięciu dylematów (ramka 1).

\section{Ramka 1 \\ Misja społeczna uniwersytetu w XXI wieku - 10 najważniejszych kierunków rozwiązań dylematów uniwersytetu}

1. Respektowanie zapotrzebowania społecznego zgłaszanego pod adresem uniwersytetów, tak by wpisały się one w niezbywalną dla uniwersytetów i społecznie doniosłą perspektywę badawczą motywowaną dążeniem do bezinteresownego poznania prawdy.

2. Zachowanie i umacnianie właściwej uniwersytetowi autonomii - z gotowością poddania społecznej kontroli przejrzystych reguł dotyczących programów badań naukowych, dydaktyki, awansu naukowego i zarządzania uniwersytetem.

3. Kultywowanie etosu akademickiego sprzyjającego rozwojowi nauki i edukacji uniwersyteckiej, stosującego jednak we własnym systemie zarządzania reguły i mechanizmy działania właściwe dla wszystkich instytucji publicznych.

4. Takie kształcenie studentów, które pozwoli im elastycznie i kreatywnie wejść na rynek pracy.

5. Dbałość o jakość kształcenia, przejrzystą i harmonizującą z misją uniwersytetu, uwzględniająca trzy jego wymiary: przekaz wiedzy, wyposażanie w umiejętności i kształtowanie postaw.

6. Integralne, humanistyczne formowanie studentów, tak by mogli aktywnie i odpowiedzialnie uczestniczyć w życiu publicznym.

7. Jasne i wiarygodne zdefiniowanie misji poszczególnych uniwersytetów, uwzględniające ich różnorodność.

8. Troska o rozwój elitarnych uniwersytetów i kierunków studiów, podejmujących najważniejsze naukowe wyzwania i kształcące ludzi uczestniczących w rozwoju nauki w wymiarze światowym.

9. Organizowanie i rozwijanie edukacji szerokich warstw społecznych, z wykorzystaniem osiągnięć naukowo-technicznych, zwłaszcza Internetu (tzw. life-long learning).

10. Obecność uniwersytetów w życiu publicznym, wspierająca ducha racjonalnego dialogu społecznego.

Źródło: Woźnicki 2015b: 25. 
Warto traktować powyższe sugestie jako swoisty opis typu idealnego współczesnego uniwersytetu (w sensie typu idealnego Webera) - modelu, który nie ma i raczej nie będzie mieć odpowiednika w rzeczywistości. Wszystkie opisane w misji elementy nie mogą bowiem jednakowo funkcjonować we wszystkich rodzajach uczelni.

Drugą kwestią, która stanowi swego rodzaju wizytówkę Programu, jest deregulacja systemu szkolnictwa wyższego w Polsce, której poświęcono część V dokumentu. Autorzy dokumentu, pisząc o narastającej w ostatnich latach presji o charakterze „deregulacyjnym”, postawili „tezę o potrzebie odwrócenia tych tendencji w wyniku przyjęcia nowych założeń kulturowych, merytorycznych i metodologicznych w procesie dalszego stanowienia prawa w odniesieniu do szkolnictwa wyższego, tak aby zostały osiągnięte efekty zauważalnej deregulacji systemu, zgodnie z zasadami pomocniczości i proporcjonalności" (Woźnicki 2015c: 37). Za postulatem deregulacji stoi konieczność wyboru tego, co powinno być przedmiotem regulacji ustawowych, w szczególności tych o charakterze fundamentalnym, określających model instytucjonalny uczelni i jej relacje z interesariuszami wewnętrznymi i zewnętrznymi, oraz jakie powinno być brzmienie tych regulacji (Woźnicki 2015b: 11). Generalnie autorzy raportu postulują regulowanie wymogów przejrzystości uczelni i obszarów gwarancji praw, reguł weryfikacji uzyskiwania efektów oraz zasad nadzoru, natomiast deregulowanie sposobów i ścieżek uzyskiwania efektów i procedur (Woźnicki 2015b: 27). Opracowanie zawiera 40 rekomendacji zestawionych w następujące grupy: (1) rekomendacje dotyczące konstytucyjnych podstaw regulacji szkolnictwa wyższego, (2) rekomendacje o charakterze regulacyjnym, (3) rekomendacje deregulacyjne o charakterze systemowym, (4) rekomendacje dotyczące procesu kategoryzacji jednostek naukowych, (5) przykładowe rekomendacje szczegółowe. Intencją autorów Programu kryjącą się za tymi rekomendacjami jest doprowadzenie do opracowania i przyjęcia do 2020 r. nowej ustawy - zderegulowanego Prawa o szkolnictwie wyższym (Woźnicki 2015a: 50).

Konferencja Rektorów Akademickich Szkół Polskich, postulując w Programie deregulację na poziomie systemowym, podkreśliła znaczenie i potrzebę deregulacji przepisów stanowionych przez organy uczelni, gdyż uczelniane regulacje zazwyczaj są wymuszane przez wymogi prawne wyższego poziomu. Deregulacja na dwóch poziomach pozwoliłaby uczelniom na poszukiwanie w granicach prawa własnych dróg rozwiązywania swoich problemów (Woźnicki 2015a: 50), co umożliwiłoby urzeczywistnienie zidentyfikowanej wcześniej misji społecznej uniwersytetu XXI wieku. KRASP jako interesariusz środowiskowy nie pozostaje osamotniony w sygnalizowaniu „napięć pomiędzy autonomią uniwersytetu a koniecznością poddania się sprawowanej przez państwo zewnętrznej kontroli, które niezwykle trudno pogodzić" (Woźnicki 2015b: 15). Nie jest też jedynym, który postuluje konieczność konstruktywnego dialogu społecznego na rzecz szkolnictwa wyższego i nauki. 


\section{Obywatele Nauki i Pakt dla Nauki}

Inicjatywę na rzecz szerokiej publicznej dyskusji o przyszłości nauki w Polsce podjęli Obywatele Nauki (ON), przekonani, iż „nauka jest zbyt ważna, żeby zostawić ją wyłącznie politykom"4. Jak sami o sobie mówią, ON jest nieformalnym i apolitycznym ruchem społecznym tworzącym forum dialogu wewnątrz środowiska naukowego w Polsce 5 . Swoją obecność zainicjowali manifestem, pod którym podpisało się ponad 1900 osób. W manifeście członkowie ON postulowali wyzwolenie potencjału nauki, aby normą w Polsce stała się m.in. edukacja akademicka umożliwiająca uzyskanie potrzebnych umiejętności zawodowych i społecznych poprzez rozwój intelektualny i stymulowanie krytycznego myślenia oraz osiągnięcia badawcze rozpoznawalne w świecie, powszechna i przystępna popularyzacja nauki. Za swój cel ruch przyjął opracowanie i podpisanie Paktu dla Nauki, który będzie określał kierunki polityki naukowej państwa na kolejne lata. W uzasadnieniu takiej formy dialogu z władzami publicznymi wskazał na umowę społeczną, której stronami powinny być środowiska naukowe, obywatele i władze.

W kwietniu 2015 r. Obywatele Nauki opublikowali tekst Paktu dla Nauki - obywatelskiego projektu zmian w nauce i szkolnictwie wyższym, który ,jest wynikiem oddolnej, samorządnej i obywatelskiej troski o dobro publiczne, jakimi są nauka i szkolnictwo wyższe. Dokument diagnozuje aktualne bolączki systemu (zarówno chroniczne, jak i będące następstwem kolejnych, nieskoordynowanych zmian prawnych i organizacyjnych), szukając sposobów ich rozwiązania” (Muszewska, Niesiołowski-Spanò i Pieniądz 2015: 6). Jak wynika z relacji przedstawicieli ON, w konsultacjach Paktu i debacie zorganizowanej przez ON wzięło udział 5 tys. osób, Pakt powstał własnymi siłami środowiska i bez żadnego wsparcia publicznego. Co istotne jednak dla całej debaty, to stwierdzenie autorów dotyczące życzliwego przyjęcia Paktu przez MNiSW oraz otwarcia się ministerstwa na dialog z nimi (Niesiołowski-Spanò i Pieniądz 2015). Przedstawiciel ON Łukasz NiesiołowskiSpanò (2015) w komentarzu do odzewu, z jakim spotkał się Pakt dla Nauki, nie pominął krytycznych uwag dotyczących dokumentu, które podkreślały jego zachowawczy czy też wstrzemięźliwy charakter i nieuwzględnienie wielu innych ważnych dla nauki i szkolnictwa kwestii.

${ }^{4}$ http://obywatelenauki.pl/2012/o9/tezy-on-w-skrocie/ [7.07.2015].

${ }^{5} \mathrm{Na}$ pytanie o formalny status ON Aneta Pieniądz odpisała, iż „ze świadomością zrezygnowaliśmy z instytucjonalizacji ruchu, czyli tworzenia sformalizowanych struktur organizacyjnych: nie jesteśmy ani stowarzyszeniem, ani fundacją, formalnie nie mamy osobowości prawnej. Jeśli chodzi o początki ruchu, to ON nie mają swojej daty powołania. Pierwsze spotkania miały miejsce wiosną 2012 r., jednak o pomyśle na ruch społeczny dyskutowano już w 2011 r.” 
Autorzy Paktu skoncentrowali się na 12 kwestiach, które zostały przedstawione według schematu obejmującego cele, bariery i rozwiązania. Poruszone kwestie to: finansowanie nauki, współpraca nauki i biznesu, szkolnictwo wyższe, akredytacja, Polska Akademia Nauk, administracja, modele kariery naukowej, doktoranci, popularyzacja, edukacja, otwarty dostęp w nauce oraz etyka i dobre praktyki w instytucjach naukowych. Swoje stanowisko w debacie ujęli w formie 10 postulatów.

\section{Ramka 2 \\ Pakt dla Nauki - 10 najważniejszych postulatów Obywateli Nauki}

1. Podniesienie jakości badań naukowych.

2. Wzmocnienie roli uczelni, w tym uczelni lokalnych, jako ośrodków budowania kapitału społecznego, ekonomicznego i cywilizacyjnego.

3. Zatrzymanie i odwrócenie procesu pauperyzacji środowiska naukowego.

4. Uelastycznienie i zróżnicowanie modelu kariery naukowej oraz uzależnienie dróg awansu wyłącznie od kryteriów merytorycznych.

5. Wzmocnienie związku między wszystkimi etapami kształcenia, od przedszkola do szkoły wyższej - realizacja w praktyce idei ciągłości edukacji. Poprawa jakości kształcenia nauczycieli i zaangażowanie środowisk naukowych w proces doskonalenia edukacji niższych szczebli.

6. Stworzenie warunków do upowszechniania wiedzy i popularyzacji wyników badań, zwłaszcza tych finansowanych ze środków publicznych.

7. Zapewnienie przestrzegania standardów etycznych w środowiskach naukowych. Przestrzeganie Europejskiej Karty Naukowca oraz Kodeksu postępowania przy rekrutacji pracowników naukowych.

8. Podniesienie nakładów budżetowych na naukę do co najmniej 1\% PKB (bez wliczania środków unijnych) do 2020 r. i do co najmniej 2,5\% PKB do 2030 r.; zapewnienie finansowania publicznych uczelni wyższych w wysokości odpowiadającej kosztom funkcjonowania.

9. Stworzenie skutecznych mechanizmów i procedur służących wzmacnianiu współpracy między naukowcami i gospodarką, uproszczenie drogi od wynalazku do wdrożenia.

10. Nowa spójna organizacja uczelni publicznych, oparta na jasnych i zobiektywizowanych kryteriach jakości prowadzonych badań naukowych i jakości kształcenia.

Źródło: Muszewska, Niesiołowski-Spanò i Pieniądz 2015: 7.

Postulaty te głównie tym różnią się od przesłania płynącego ze społecznej misji uniwersytetu autorstwa KRASP, że kładą nieco większy nacisk na znaczenie uczelni lokalnych, a nie elitarnych oraz na wszechstronne powiązanie wszystkich etapów kształcenia, a nie tylko wzmacnianie uczenia się dorosłych. Pisząc osobno w Pakcie o szkolnictwie wyższym, Obywatele Nauki wskazali na potrzebę zrównoważonego rozwoju szkolnictwa wyższego, które zakłada całościowe rozpatrywanie systemu jako sumy powiązanych elementów różniących się co do przypisanych im zadań, a tym samym dróg rozwoju. Niczym nowym nie jest stwierdzenie ON, że uczelnie akademickie powinny łączyć działalność dydaktyczną z działalnością badawczą. Niemniej ON postulują, podobnie jak KRASP, inny model zarządzania i finansowania dla uczelni o odmiennych zadaniach. Proponują modelowe zróż- 
nicowanie typów uczelni i ich działalności na uczelnie o największym, mniejszym i słabym potencjale naukowym (Muszewska, Niesiołowski-Spanò i Pieniądz 2015: 21-24).

Wskazywana przez KRASP i ON konieczność funkcjonowania uczelni o odmiennych misjach i specyfice działania w ramach ujednoliconego i mało elastycznego systemu prawnego i finansowego wydaje się główną przyczyną antagonizmów między państwem a uniwersytetami. Trudno nie zgodzić się z tym, że poszczególne uczelnie mają nieco odmienne misje edukacyjne i badawcze oraz odmienne uwarunkowania lokalne, które wpływają na ich zapotrzebowania (finansowe, kadrowe, lokalowe itd.) czy kształt oferty edukacyjnej i naukowej. Choć ta odmienność nie tkwi wyłącznie w podziale na uniwersytety i inne uczelnie, jednak zarzewiem sporu w debacie publicznej staje się typowa dla uniwersytetów - raczej mało rynkowa - działalność naukowa i badawcza w zakresie humanistyki.

\section{Okrągły Stół Humanistyki i ministerialny „Pakiet dla humanistyki”}

Niezależnie od formalnych działań KRASP czy nieformalnych działań ON, reprezentanci tego środowiska indywidualnie i spontanicznie podejmowali inicjatywę włączenia się w debatę o losach uniwersytetu i całego szkolnictwa wyższego w Polsce. Próbą zwrócenia uwagi decydentów na ich postulaty były listy otwarte sygnowane przez środowisko polskich humanistów, które pojawily się w kolejnych trzech miesiącach na przełomie 2013 i 2014 r. List w obronie filozofii z 30 grudnia 2013 r. oraz list starożytników z 23 stycznia 2014 r. dopełnił kolejny list - kulturoznawców i badaczy kultury z 17 lutego 2014 r. Stający w obronie kształcenia i badań w zakresie humanistyki autorzy listów słusznie podkreślali znaczenie humanistyki dla rozwoju polskiego społeczeństwa, nie zgadzając się na negatywne dla niej skutki w polityce wobec uniwersytetów $w^{6}$. Wspomniane listy otwarte jako narzędzia perswazyjne służące zwróceniu opinii publicznej uwagi na daną sprawę oraz sprowokowaniu adresata do zajęcia w opisywanej sprawie określonego stanowiska w pewnym sensie spełniły jednak swoją rolę, gdyż wywołały określone posunięcia MNiSW.

Z inicjatywy minister nauki i szkolnictwa wyższego prof. Leny Kolarskiej-Bobińskiej w dniu 26 lutego 2014 r. zostało zorganizowane spotkanie pod nazwą Okrągły Stół Humanistyki. Trudno doszukać się oficjalnej relacji ministerstwa z tej debaty, są natomiast dostępne sprawozdania komentatorów zewnętrznych, $\mathrm{w}$ tym interesariuszy środowiskowych. Informację o tym wydarzeniu zamieszczoną w numerze 3 Forum Akademickiego z 2014 r. rozpoczęły słowa: „Okrągły stół

\footnotetext{
${ }^{6} \mathrm{Z}$ uwagi na ograniczenia związane z długością artykułu nie przytaczam treści tych listów.
} 
humanistyki... okazał się trochę kanciasty”. Kładła ona nacisk na odmienne podczas spotkania oceny kondycji polskiej humanistyki i różne propozycje dotyczące jej przyszłości. Wniosek płynący z tej informacji był taki, że dyskutantów dzieliły w zasadzie wszystkie poruszane zagadnienia poza jednym - koniecznością pracy nad kryteriami oceny jednostek z obszaru nauk humanistycznych, w tym kryteriami oceny monografii.

Sprawozdanie ze spotkania przygotowali również członkowie ruchu Obywatele Nauki. Z relacji tej wynika, że po części, na której zgromadzeni wypowiadali się o kondycji polskiej humanistyki, nastąpiła część ministerialna, podczas której zaprezentowano „Pakiet dla humanistyki”. Pani minister zadeklarowała, oprócz modyfikacji ustawowego zapisu o odpłatności za drugi kierunek studiów, wprowadzenie zapisu dotyczącego konieczności oferowania wszystkim studentom w toku studiów puli zajęć ogólnouczelnianych, plany włączenia kierunków studiów oferujących umiejętności „miękkie” do programu kierunków zamawianych, a także zapowiedziała kontynuację konkursu na wyróżniające się programy studiów. W ramach prezentowanego „Pakietu dla humanistyki” pojawiła się również zapowiedź podjęcia rozmów na temat uwzględnienia specyfiki nauk humanistycznych w modyfikacji kryteriów ocen jednostek naukowych oraz kontynuacji Narodowego Programu Rozwoju Humanistyki (NPRH). Interesującą ocenę Okrągłego Stołu Humanistyki w dzień po nim przedstawił na łamach swojego blogu naukowego „Warsztat badacza” Emanuel Kulczycki (2014). Pomimo uwagi, że przed spotkaniem „Nikt do końca nie wiedział, o co chodzi w tym »Stole...«, stwierdzil, że spotkanie było przede wszystkim potrzebne jako "gest symboliczny« ale też, że nie udało się niczego wypracować poza deklaracją, że potrzebne są jak najszybciej robocze "podstoliki «". O tym, jaką rolę w debacie o humanistyce spełniło to spotkanie, mogą świadczyć przywołane przez tego autora słowa jednego z uczestników, iż „wiele głosów podnoszonych w dyskusji dotyczyło przede wszystkim całej nauki, zasad jej finansowania i oceny - a nie ściśle humanistyki”. Jednak Okrągły Stół Humanistyki wywołał dyskusję o humanistyce, a dokładnie o konieczności jej umiędzynarodowienia (Antonowicz, Bilewicz i Kulczycki 2014a; 2014b). Również w opinii Komitetu Kryzysowego Humanistyki Polskiej zabrakło dyskusji o humanistyce. KKHP zarzuciło ministerstwu, że wydaje się sugerować, iż polscy naukowcy są leniwi i mało zaradni, co stanowić ma domniemaną przyczynę słabej kondycji polskiej nauki. W swojej relacji ze spotkania z Leną Kolarską-Bobińską KKPH nie szczędziło krytyki pod adresem pani minister, której odpowiedź została zinterpretowana jako „wymijająca i ogólnikowa”. KKHP uznał, że „konkrety, które usłyszeliśmy, idą w dobrym kierunku, ale są dalece niewystarczające i przypominają bardziej operacje wizerunkowo-piarowe niż faktyczne rozwiązania”. Odnosząc się do ministerialnych deklaracji dalszych prac i spotkań, zarzucono MNiSW brak „zarysowanej perspektywy decyzyjnej czy ustawodawczej, która dawałaby nadzieję, że z owych prac i spotkań coś konkretnego i pozytywnego wyniknie”. W sprawozda- 
niu znalazły się informacje o poruszanych w dyskusji kwestiach, takich jak nakłady na naukę, skuteczność w zdobywaniu grantów, radzenie sobie humanistów na rynku pracy oraz studia na drugim kierunku.

Analiza dostępnych relacji z Okrągłego Stołu Humanistyki nie pozwala na rzetelną i obiektywną rekonstrukcję tej dyskusji, gdyż wszystkie trzy analizowane materiały były dość krótkie i bardzo wybiórcze ${ }^{7}$. Najbardziej neutralnym przekazem dotyczącym tego spotkania było sprawozdanie Obywateli Nauki, najbardziej nacechowanym emocjonalnie, ale też uwypuklającym charakter relacji z ministerstwem - informacja KKHP. W efekcie Okrągłego Stołu Humanistyki w dniu 27 marca 2014 r. minister Lena Kolarska-Bobińska napisała do polskich humanistów list, w którym podkreśliła potrzebę kompleksowego wsparcia humanistyki, dbałości o jej odpowiednie znaczenie w całym procesie kształcenia na poziomie wyższym, a także promowania i upowszechniania, zwłaszcza na arenie międzynarodowej ${ }^{8}$. Jednak list informuje głównie o pracach podjętych $\mathrm{w}$ celu realizacji „Pakietu dla humanistyki”. Pani minister, odwołując się do obrad Okrągłego Stołu Humanistyki, poinformowała o utworzeniu trzech zespołów: zespołu ds. zwiększania aktywności i udziału polskich naukowców w programie Horyzont 2020 i innych międzynarodowych programach grantowych, zespołu ds. wypracowania mechanizmów wzmacniających interdyscyplinarność badań naukowych i studiów oraz zespołu ds. zajęć ogólnouniwersyteckich.

Niezadowolenie ON oraz KKHP z przebiegu obrad Okrągłego Stołu Humanistyki świadczy o braku dialogu między MNiSW a interesariuszami środowiskowymi. Spotkanie zorganizowane przez ministerstwo obliczone zostało na spełnienie swego rodzaju nakazu chwili do jakiegokolwiek zareagowania na publiczne głosy krytyki. Nie poszły za tym starania MNiSW w kierunku wypracowania kompromisu, nastąpiło jedynie zaprezentowanie własnej linii działania i przedsięwziętych wcześniej zamysłów.

\section{Komitet Kryzysowy Humanistyki Polskiej, czyli „nic o nas bez nas"}

Najbardziej radykalnym w swoich działaniach przeciwko decyzjom MNiSW interesariuszem środowiskowym jest Komitet Kryzysowy Humanistyki Polskiej, który wyłonił się jako grupa w toku debat i wspólnych działań w grudniu 2013, natomiast w kwietniu 2014 r. ukonstytuował się jako stowarzyszenie. Za oficjal-

7 W sprawozdaniu ON dotyczącym Okrągłego Stołu Humanistyki jest zapis, iż MNiSW zapowiedziało opublikowanie stenogramu lub zapisu wideo całej debaty. W czasie powstawania tego artykułu nie było bezpośredniej relacji ministerstwa z tego spotkania.

${ }^{8}$ https://www.nauka.gov.pl/g2/oryginal/2014_03/7982docccf7ad9165f1b4488coc313dd.pdf [20.07.2015]. 
ny swój cel KKPH przyjął działanie na rzecz przezwyciężania kryzysu zinstytucjonalizowanej nauki, zwłaszcza humanistyki, oraz integrację środowisk, którym los nauki nie jest obojętny. Jednym z pierwszych działań KKPH było przygotowanie pod koniec grudnia $2013 \mathrm{r}$. listu otwartego w obronie filozofii do minister Kolarskiej-Bobińskiej, który ugrupowanie to nazwało największym listem otwartym po 1989 r. KKPH określa się jako animator kolejnych, przywołanych już wyżej, listów otwartych - starożytników i kulturoznawców.

$\mathrm{W}$ opublikowanym na swojej stronie WWW' pierwszym numerze biuletynu In-formacja (z 2015 r.) autorzy piszą, iż Komitet powstał z inicjatywy przedstawicieli nauk humanistycznych, głównie młodych pracowników naukowych i doktorantów, których zaniepokoiły projekty likwidowania, uznanych za nieopłacalne, na niektórych uczelniach humanistycznych kierunków studiów. KKPH rozszerzyło jednak swoją akcję także na inne „deficytowe” dla państwa kierunki studiów niż humanistyczne czy humanistyczno-społeczne: przyrodnicze i ścisłe oraz artystyczne.

W lutym 2015 r. KKPH zorganizował w Fundacji Batorego, we współpracy ze wszystkimi działającymi na uniwersytetach związkami zawodowymi, kongres „Kryzys uczelni - kryzys nauki - kryzys pracy. Diagnozy, postulaty, rozwiązania”. W trakcie kongresu wysunięto trzy postulaty, które były potem dopracowywane. Generalnie dotyczyły one takiego „systemu finansowania, który wymusi na jednostkach naukowych podwyższenie poziomu prowadzonych w nich badań, $w$ taki sposób, aby została zachowana ich ciągłość instytucjonalna w czasie niżu demograficznego, nie zaś systemu, który ostatecznie uniemożliwi prowadzenie badań w jednostkach mniejszych i nie-wielkomiejskich lub prowadzących mniej popularne kierunki studiów". Pod postulatami podpisało się 70 instytutów i wydziałów ze wszystkich uniwersytetów, zarówno reprezentujących nauki humanistyczne (filologie, filozofia, teologia, historia, archeologia, etnologia i antropologia, kulturoznawstwo, historia sztuki czy z obszaru sztuki: muzykologia) i społeczne (pedagogika, socjologia, politologia, studia regionalne), jak i ścisłe (fizyka). W ogłoszonych w czasie kongresu antykryzysowych postulatach KKPH, wzywając rząd do odstąpienia od antyrozwojowej polityki, oświadczyl, iż „zignorowanie kolejnego wystąpienia świata naukowego nie pozostawi już Uniwersytetowi innej drogi niż protesty" (Postulaty antykryzysowe z 3.02.2015).

Efektem prac zespołów roboczych KKPH podczas kongresu i po nim było przedstawienie wiceministrowi Markowi Ratajczakowi na spotkaniu w dniu 17 marca 2015 r. postulatów pogrupowanych w pięć obszarów problemowych:

- zmiany systemu finansowania szkolnictwa wyższego,

- reforma systemu finansowania nauki,

- zmiana zasad oceniania jakości badań naukowych,

9 http://komitethumanistyki.pl/wp-content/uploads/2015/o5/informacja.pdf [21.07.2015]. 
- zmiany modelu kariery naukowej i poprawa warunków studiowania w szkołach wyższych,

- zmiana modelu współpracy uczelni z otoczeniem społecznym.

W informacji o spotkaniu na swojej stronie internetowej MNiSW zapowiedziało, że odpowie pisemnie na postulaty KKHP, oraz wyraziło gotowość do dalszych rozmów z przedstawicielami Komitetu na temat toczących się prac zmieniających sytuację polskiej humanistyki. Niemniej w oświadczeniu KKHP z 18 marca 2015 r. przedstawiciele ugrupowania stwierdzili, iż ministerstwo odrzuciło możliwość wspólnej pracy nad palącymi problemami, a spotkanie nie stało się okazją do podjecia dialogu społecznego na temat kryzysu polskiej nauki. Spotkanie uznano za pełniące dla ministerstwa funkcję czysto wizerunkową, co „stawia pod znakiem zapytania możliwość dialogu społecznego i uniemożliwia wdrożenie niezbędnych i niecierpiących zwłoki reform", a w rezultacie zmusza środowisko naukowe do dalszej mobilizacji (Oświadczenie KKHP z 18.03.2015). W odpowiedzi z dnia 19 marca 2015 r. wiceminister Marek Ratajczak wspomniał o pracach ministerstwa nad zmianami w szkolnictwie wyższym, w tym o zmianach finansowania szkolnictwa wyższego po przyjęciu strategii. Wyraził przy tym gotowość do przyjęcia opinii $\mathrm{KKPH}$, argumentując ją koniecznością szerokiej dyskusji z różnymi grupami ${ }^{10}$. $\mathrm{W}$ dniu 7 kwietnia $2015 \mathrm{r}$. MNiSW przedstawiło pisemną odpowiedź na postulaty KKHP, w której ustosunkowało się do wszystkich pięciu obszarów problemowych. To jednak nie usatysfakcjonowało członków Komitetu, którzy pod wpływem opinii z lutego 2015 r. autorstwa doradcy prezydenckiego, prof. Macieja Żylicza, na temat postulatów KKHP w kwietniu 2015 r. wystosowali list otwarty do prezydenta i kandydata na prezydenta Bronisława Komorowskiego. W liście zwrócono uwagę na dezawuujący dużą część środowiska naukowego i arogancki charakter owej opinii, która zarzuca ignorancję popierającym postulaty KKHP 70 instytutom i wydziałom uniwersyteckim. Prof. Żylicz stwierdził bowiem, że protesty KKHP nie zasługują na jakąkolwiek reakcję głowy państwa, gdyż nie są reprezentatywne dla całego środowiska humanistycznego i nauk społecznych, nie są merytoryczne i zawierają nieprawdziwe informacje. W polemice w sprawie opinii doradcy prezydenta Komitet podsumował tę publiczną dyskusję słowami, że opinia prof. Żylicza jest smutnym świadectwem „zadziwiającej pogardy dla "protestujących humanistów « oraz wyrazem typowego dla urzędników raczej niż dla ludzi nauki myślenia formalno-technokratycznego".

Wyrazem niezadowolenia KKPH z reakcji władz publicznych stał się zorganizowany w dniu 19 maja 2015 r. pod Ministerstwem Nauki i Szkolnictwa Wyższego wykład okupacyjny, w którym udział wzięło czworo reprezentantów środowiska humanistów. Po wykładzie doszło do burzliwej dyskusji, do której włączyła się

${ }^{10} \mathrm{http}: / /$ komitethumanistyki.pl/2015/03/25/wymiana-listow-Z-ministerstwem/\#more-179 [21.07.2015]. 
też pani minister. W sprawozdaniu jednej osoby spośród czwórki wykładowców „okupacyjnych”, prof. Ewy Graczyk (KKHP. Sprawozdanie z protestu... 2015), mowa jest o wspólnym głosie wymierzonym w generujące zagrożenie Ministerstwo. Autorka ta w wykładzie pt. Po nas choćby potop działania „zafundowane” uniwersytetowi nazwała planem Balcerowicza bis, który jest podporządkowany wąsko rozumianej logice ekonomicznej efektywności niosącej ogromne koszty dla społeczeństwa polskiego. Podkreślając coraz większą arogancję władzy, autorka zwróciła się do wszystkich wydziałów humanistycznych z prośbą o wywieszenie flag żałobnych na znak protestu przez trzy dni w czerwcu $2015 \mathrm{r}$.

W dniu 10 czerwca br. na budynkach poszczególnych wydziałów 15 polskich uniwersytetów wywieszono na trzy dni czarne flagi. Tego samego dnia rozczaro-

Tabela 1. Postulaty KKHP i odpowiedź MNiSW

\begin{tabular}{|l|l|l|}
\hline \multicolumn{1}{|c|}{ Postulat KKHP } & \multicolumn{1}{|c|}{ Uzasadnienie KKHP } & \multicolumn{1}{c|}{ Odpowiedź MNiSW } \\
\hline $\begin{array}{l}\text { Uniezależnienie } \\
\text { finansowania } \\
\text { uniwersytetów od } \\
\text { liczby studentów }\end{array}$ & $\begin{array}{l}\text { Niż demograficzny jako szansa na po- } \\
\text { prawę jakości kształcenia. Mniejsze } \\
\text { pensum kadry jako szansa na zwięk- } \\
\text { szenie czasu na badania i rozwój. }\end{array}$ & $\begin{array}{l}\text { Finansowanie uczelni tylko w 12\% } \\
\text { zależy bezpośrednio od liczby studen- } \\
\text { tów. Nie może być sytuacji, w której } \\
\text { uczelnia bez żadnego studenta byłaby } \\
\text { finansowana przez państwo. }\end{array}$ \\
\hline Wiedza to nie towar & $\begin{array}{l}\text { Zmiana sposobu oceny badań i wpro- } \\
\text { wadzenie innych mierników oceny } \\
\text { projektów badawczych dla nauk ści- } \\
\text { słych i humanistycznych. Odbiuro- } \\
\text { kratyzowanie uniwersytetu i zmniej- } \\
\text { szenie ilości pracy administracyjnej } \\
\text { narzuconej kadrze akademickiej. }\end{array}$ & $\begin{array}{l}\text { Planowane jest rozporządzenie, któ- } \\
\text { re zmieni system ocen i w większym } \\
\text { styki. }\end{array}$ \\
\hline $\begin{array}{l}\text { Zmniejszenie udziału grantów na rzecz } \\
\text { stabilnego finanini specyfikę humani- } \\
\text { uniwersyteckich. }\end{array}$ & $\begin{array}{l}\text { Polityka naukowa w Europie oparta } \\
\text { jest na systemie grantowym. W Pol- } \\
\text { sce w 2014 r. finansowanie humani- } \\
\text { styki było oparte na grantach tylko } \\
\text { w 15,5\%, reszta to finansowanie sta- } \\
\text { tutowe (jak postuluje KKHP). }\end{array}$ \\
\hline $\begin{array}{l}\text { Samorząąy } \\
\text { i organizacje poza- } \\
\text { rządowe partnerem } \\
\text { uniwersytetów }\end{array}$ & $\begin{array}{l}\text { Ustawowo jedynym partnerem uni- } \\
\text { wersytetów są firmy. Konieczna jest } \\
\text { współpraca z samorządami, NGOsa- } \\
\text { mi i związkami zawodowymi. }\end{array}$ & $\begin{array}{l}\text { Ustawa pozwala uczelniom współ- } \\
\text { pracować z otoczeniem społecznym. } \\
\text { Związki zawodowe, samorządy oraz } \\
\text { NGOsy mogą wchodzić w skład kon- } \\
\text { wentów uczelni. }\end{array}$ \\
\hline $\begin{array}{l}\text { Realny wzrost } \\
\text { finansowania nauki }\end{array}$ & $\begin{array}{l}\text { Urealnienie wzrostu finansowania do } \\
\text { 2020 r. 1,2\% PKB (zamiast do 2\%). } \\
\text { Celem jest utrzymywanie infrastruk- } \\
\text { tury, a nie jej budowa (fenomen pu- } \\
\text { stych laboratoriów). }\end{array}$ & $\begin{array}{l}\text { W 2015 r. wzrost nakładów o 10\% na } \\
\text { naukę i o 6\% na szkolnictwo wyższe. } \\
\text { Zabiegi na rzecz kolejnego wzrostu } \\
\text { w 2016 r. }\end{array}$ \\
\hline
\end{tabular}

Źródło: opracowanie własne na podstawie informacji MNiSW z 10 czerwca 2015 r. 
wana coraz bardziej wdrażanymi reformami społeczność KKPH zorganizowała „Czarną Procesję Nauki”. Manifestanci w liczbie ok. 200 osób udali się pod Kancelarię Prezesa Rady Ministrów, by w milczącym marszu wręczyć rządzącym swoje postulaty. W oświadczeniu na własnej stronie internetowej KKHP poinformowała, że studenci i pracownicy nauki (niczym Stan Trzeci czasów Oświecenia) nie godzą się na marazm i degradację publicznych instytucji. Pod hasłami niezgody „na feudalizację uczelni i podporządkowanie ich logice rynkowej i urzędniczej biurokracji” zażądano „prawdziwych reform” (KKHP. Czarna procesja nauki 2015). W dniu procesji MNiSW po raz drugi opublikowało na swojej stronie internetowej odpowiedź na postulaty KKHP.

Pomimo pewnej wybiórczości przedstawionych wyżej postulatów KKHP i odpowiedzi ministerstwa na te kwestie, zestawienie to pokazuje całkowite rozmijanie się obu stron w przytaczanych argumentach i jeszcze większą potrzebę merytorycznego dialogu. KKHP są przeciwni zacieraniu różnic między uniwersytetami a szkołami wyższymi, które nazywane są uniwersytetami na wyrost. W swych założeniach programowych postulują zachowanie na uniwersytetach równowagi między wszystkimi dziedzinami wiedzy. Tym samym postulaty KKPH wpisują się ideę dywersyfikacji instytucji szkolnictwa wyższego, a co za tym idzie - innego ich finansowania i zarządzania, czego nie zapewnią centralne i jednolite regulacje prawne.

Jak wynika z opisanej tu historii wzajemnych relacji KKHP z MNiSW, trudno mówić o woli porozumienia między nimi. Nie świadczy też o tym nawet obecność przedstawiciela KKHP na konferencji zorganizowanej przez MNiSW w dniu 24 czerwca 2015 r., podczas której miały być zaprezentowane stanowiska i propozycje innych uczestników debaty, tj. KRASP i ON. Komitet nie został zatem potraktowany przez ministerstwo jako równoprawny partner w dyskusji.

\section{Realny czy pozorowany dialog...}

Konferencja z udziałem 400 osób, zorganizowana przez MNiSW w dniu 24 czerwca 2015 r. pt. „Jakie mają być nasze uczelnie i polska nauka?”, miała być w zamyśle MNiSW świadectwem otwartej debaty na temat przyszłości polskiego szkolnictwa wyższego i nauki. We wprowadzeniu do obrad minister Lena Kolarska-Bobińska uwypukliła wyjątkowość tego wydarzenia, w tym możliwość spotkania się w jednym miejscu „przedstawicieli różnych koncepcji, różnych poglądów, różnych pomysłów, jak ma wyglądać przyszłość naszego szkolnictwa” oraz przewidując w przyszłości kontynuację dyskusji (MNiSW. Stenogram 1 2015: 2). Natomiast na zakończenie konferencji minister podsumowała, że dyskusja służyła nie tylko zaprezentowaniu ministerialnego dokumentu, ale zawierała też dużo konkretnych 
pomysłów, pokazała właściwe proporcje między tym, co zależy od ministerstwa, a co od nas samych, i wykazała, że środowisko chce dokonywać zmian i o tych zmianach rozmawia (MNiSW. Stenogram 3 2015: 37)

Lektura stenogramów z trzech paneli ${ }^{11}$ prowadzi do wniosku, że rzeczywiście spotkanie miało na celu - jak skomentowali to Obywatele Nauki - głównie „poznanie i szlifowanie własnych stanowisk niż konstruktywny dialog i prace nad rozwiązaniami” (Obywatele Nauki. Marcin Zaród o debacie... 2015). Zabrakło po tej dyskusji zapewnień, że konkretne propozycje środowiska zostaną wzięte pod uwagę w reformowaniu szkolnictwa wyższego w Polsce. Ministerstwo zapowiedziało jedynie, że opinie i wnioski z debaty będą analizowane, a na przełomie września i października przedstawiony zostanie całościowy program dotyczący przyszłości szkolnictwa wyższego i nauki w Polsce (Mikołajczyk i Pawlaczyk 2015: 6). Rzeczywiście, 30 września 2015 r. MNiSW ogłosiło „Program rozwoju szkolnictwa wyższego i nauki na lata 2015-2030”, jest to jednak „kontynuacja i rozwinięcie działań i strategii już realizowanych w Ministerstwie" ${ }^{12}$. Trudno oprzeć się wrażeniu, że debata oparta na rozmowach ze środowiskiem, po której nie zapadły żadne decyzje ze strony ministerstwa, stanowiła raczej „specyficzny element roku wyborczego” (Obywatele Nauki. Marcin Zaród o debacie... 2015) niż przykład konstruktywnego narzędzia polityki szkolnictwa wyższego i nauki.

Przedstawione formy uczestnictwa interesariuszy środowiskowych w debacie dotyczącej szkolnictwa wyższego niewątpliwie dowodzą niezadowolenia części środowiska akademickiego z działań reformatorskich MNiSW. Osią tej dyskusji o uniwersytetach jest starcie dwóch stanowisk: idealistyczno-humanistycznego, czyli stronników tradycyjnej wizji uniwersytetu opartego na wartościach kulturowych, oraz pragmatyczno-rynkowego, czyli stronników wizji współczesnego uniwersytetu wychodzącego naprzeciw wartościom bardziej utylitarnym i merkantylnym, wpisującym się w ideologię gospodarki wiedzy. Stronę obrońców wizji tradycyjnej przyjmują przy tym przedstawiciele wspólnoty akademickiej, zaś stronę ofensywy promującej nieodwołalną już zmianę - reformatorzy, czyli organy władzy publicznej. Nie ma tu miejsca na roztrząsanie racji każdej ze stron (Dziedziczak-Foltyn 2014), jednak na podstawie przytoczonych stanowisk można odtworzyć apel środowiska akademickiego, aby różnicować politykę i prawo w zależności od rodzaju uczelni, co pozwoli zachować owe wartości idealistyczno-humanistyczne typowe dla formuly uniwersytetu. Jak dotąd apel ten jest przez ministerstwo ignorowany. Natomiast zestawienie postulatów i działań podejmowanych przez „ofensywę” (MNiSW) i „obronę” (interesariusze wewnętrzni) w tej

${ }^{11} \mathrm{Na}$ konferencję złożyły się trzy panele: (1) Przyszłość szkolnictwa wyższego w Polsce: cele, struktury, mechanizmy finansowania, (2) Nauka w zmieniającym się świecie, (3) Ścieżki kariery akademickiej i naukowej. Na stronie MNiSW są też dostępne nagrania ze wszystkich paneli.

${ }^{12} \mathrm{http}$ ///www.nauka.gov.pl/aktualnosci-ministerstwo/program-rozwoju-szkolnictwa-wyzszego-i-nauki-na-lata-2015-2030.html [30.09.2015]. 
rozgrywce o losy uniwersytetu prowadzi do wniosku, że nie było warunków dla prawdziwie demokratycznie ukonstytuowanego dialogu pomiędzy tymi interesariuszami: organami państwa i środowiskiem akademickim. Ów brak porozumienia między państwem a środowiskiem akademickim wynika zapewne z niestabilności reform i permanentnych renegocjacji tych relacji (Kwiek 2013: 267). Jest skutkiem nieumiejętności budowania konsensusu co do kształtu przyszłych reform z najważniejszymi interesariuszami, która jest warunkiem sine qua non ekonomii politycznej reform (Kwiek 2010: 389). Odwołując się do perspektywy zarządzania publicznego, można mówić o hierarchizującej roli państwa w relacjach z interesariuszami polityk publicznych w Polsce. Państwo bowiem stosuje model zarządzania poprzez legislację, w którym rządzący mają skłonność do podejmowania jednostronnych działań, zaniedbując proces deliberacji w tworzeniu polityki (Zybała 2013: 33-35). Co więcej, zdolność państwa do reformowania to także integrowanie interesariuszy i tworzenie wraz z nimi koła uczenia się (Zybała 2013: 162). W przypadku polskiego profilu deliberacji podstawowym podmiotem pozostaje jednak państwo (rząd), które organizuje i kontroluje przebieg deliberacji, wybierając partnerów i określając metody wymiany poglądów i wiedzy (Zybała 2013: 216). Dlatego być może największym poważaniem ze strony MNiSW cieszyły się opisane w artykule działania Konferencji Rektorów Akademickich Szkół Polskich, całkiem sporą uwagą - także działania Obywateli Nauki, natomiast protesty Komitetu Kryzysowego Humanistyki Polskiej traktowane były przez decydentów $\mathrm{z}$ dużym dystansem. Być może wpływ na to miała jakość proponowanych opracowań, gdyż w przypadku KRASP mowa jest o bardzo obszernym i szczegółowym dokumencie, nad którym pracował cały sztab ekspertów i który był wielokrotnie konsultowany w środowisku. Pakt dla Nauki ON także powstał w toku szeroko zakrojonych konsultacji. Pod hasłami KKHP podpisały się z kolei, przystępując do protestu z flagami, wydziały humanistyczne i nauk społecznych, miało to jednak wymiar bardziej symboliczny niż merytoryczny i sprawczy.

Za swego rodzaju zwiastun zmiany w relacjach między państwem a środowiskiem akademickim można przyjąć zorganizowanie przez decydentów Okrągłego Stołu Humanistyki. Jednak coraz bardziej radykalne w swej wymowie protesty KKPH pokazują, że działanie to jest pozorne i niezadowalające, przynajmniej dla pewnej części tego środowiska, które nadal jest podzielone, będąc nawet po tej samej stronie „barykady”. Trudno też uznać debatę z 24 czerwca zorganizowaną przez MNiSW za przełom w debacie o reformowaniu szkolnictwa wyższego w Polsce. Nawiązując do przytoczonej we wprowadzeniu koncepcji działań neopozornych, można uznać opisane w tekście działania władz publicznych raczej za rodzaj ceremonii publicznego komunikowania w obszarze nauki i szkolnictwa wyższego (Czyżewski 2009: 28) niż za inicjatywy służące realnemu wypracowaniu kierunków polityki w drodze konstruktywnego dialogu społecznego z interesariuszami środowiskowymi. 


\section{Literatura}

Antonowicz, D., Bilewicz, M., Kulczycki, E. (2014a). Wielki świat lub zaścianek. Forum Akademickie. 3.https://forumakademickie.pl/fa/2014/03/kronika-wydarzen/wielki-swiat-lub-zascianek/ [15.07.2015].

Antonowicz, D., Bilewicz, M., Kulczycki, E. (2014b). Uciec z peryferii nauki. Gazeta Wyborcza. 13.06.2014.http://wyborcza.pl/magazyn/1,139105,16153460,Uciec_z_peryferii_nauki.html [15.07.2015].

Bjørkquist, C. (2011). Stakeholders Regimes in Old Ideas Higher Education in New Bottles? Münster: Waxmann.

Czyżewski, M. (2009). Działania „neopozorne”. Uwagi na temat przeobrażeń komunikowania publicznego i życia naukowego. Przegląd Socjologiczny. LVIII/1: 9-31.

Dunin, K., Gdula, M. (2013). Bez filozofii uniwersytet to zawodówka dla stażystów (list otwarty). http://www.krytykapolityczna.pl/artykuly/nauka/20131230/bez-filozofii-uniwersytetzawodowka-dla-stazystow-list-otwarty [15.07.2015].

Dziedziczak-Foltyn, A. (2009). O reformowaniu szkolnictwa wyższego w Polsce w latach 19892009 i towarzyszącej temu debacie publicznej. Przegląd Socjologiczny. 3: 51-75.

Dziedziczak-Foltyn, A. (2011). Plusy i minusy reformy szkolnictwa wyższego w Polsce - próba analizy debaty publicznej. W: J. Kostkiewicz, A. Domagała-Kręcioch, M.J. Szymański (red.). Szkoła wyższa w toku zmian. Debata wokół ustawy z 18 marca 2011 roku (95-117). Kraków: Impuls.

Dziedziczak-Foltyn, A. (2014). Recepcja przemian instytucji szkoły wyższej - szkic o dwóch formacjach w dyskursie naukowym. Nauka i Szkolnictwo Wyższe. 1-2(43-44): 30-45.

Forum Akademickie (2014). Okragły stót humanistyki... 3. https://forumakademickie.pl/fa/ 2014/o3/kronika-wydarzen/okragly-stol-humanistyki/ [15.07.2015].

In-Formacja (2015). Biuletyn Komitetu Kryzysowego Humanistyki Polskiej. 1. http://komitethumanistyki.pl/wp-content/uploads/2015/o6/biuletyn-nr-1.pdf [20.07.2015].

KKHP. Czarna procesja nauki. Oświadczenie. 4.06.2015. http://komitethumanistyki.pl/2015/ 06/o4/czarna-procesja-nauki/ [20.07.2015].

KKHP. Okrągły stół - spotkanie z Leną Kolarską-Bobińską (26 lutego 2015), http://komitethumanistyki.pl/wydarzenia/okragly-stol-spotkanie-z-lena-kolarska-bobinska-26-lutego-2015/ [20.07.2015].

KKHP. Oświadczenie Komitetu Kryzysowego Humanistyki Polskiej z 18.03.2015, http://komitethumanistyki.pl/2015/o3/18/oswiadczenie-komitetu-kryzysowego-humanistyki-polskiej/ [20.07.2015].

KKHP. Postulaty antykryzysowe. 3.02.2015. http://komitethumanistyki.pl/program/postulaty-antykryzysowe/ [20.07.2015].

KKHP. Sprawozdanie z protestu, który miał miejsce przez MNiSW w dniu 19 maja 2015 r. http:// komitethumanistyki.pl/wydarzenia/wyklady-okupacyjne-kkhp-przed-ministerstwem-nauki-i-szkolnictwa-wyzszego-19-maja-2015/sprawozdanie-prof-ewy-graczyk-2/[20.07.2015].

KKHP. Wymiana listów z ministerstwem. 25.03.2015. http://komitethumanistyki.pl/2015/o3/ 25/wymiana-listow-z-ministerstwem/\#more-179 [20.07.2015]. 
KRASP. Deklaracja Prezydium KRASP i Prezydium PAN z dnia 26 kwietnia 2007 r. w sprawie zasad reformowania polskiej nauki i szkolnictwa wyższego. http://www.krasp.org.pl/pl/archiwum_uchwaly_2005_2008/u_2005_2008 [10.07.2015].

KRASP. Dokument 1/V: Uchwała w sprawie konieczności przyspieszenia prac nad Strategią rozwoju szkolnictwa wyższego w Polsce. Prezydium KRASP. 12-13.09.2008. http://www.krasp. org.pl/pl/archiwum_uchwaly_2008_2012/u_2008_2012 [10.07.2015].

KRASP. Dokument 1/VI: Uchwała w sprawie realizacji strategii rozwoju szkolnictwa wyższego i nauki. Prezydium KRASP. 8-9.12.2011. http://www.krasp.org.pl/pl/uchwaly/uchwaly_ krasp [10.07.2015].

KRASP. Dokument 22/V: Uchwała w sprawie zmian w szkolnictwie wyższym stanowiących element procesu modernizacji kraju. Zgromadzenie Plenarne KRASP. 5-6.06.2009. http:// www.krasp.org.pl/pl/archiwum_uchwaly_2008_2012/u_2008_2012 [10.07.2015].

KRASP. Dokument 34/VI: Uchwała w sprawie przyjęcia opracowania Program rozwoju szkolnictwa wyższego do 2020 r. Prezydium KRASP. 27.02.2015. http://www.krasp.org.pl/pl/ uchwaly/uchwaly_krasp [10.07.2015].

KRASP. Dokument 36/V: Uchwała w sprawie przyjęcia dokumentu Strategia rozwoju szkolnictwa wyższego 2010-2020 - projekt środowiskowy. Załączniki do uchwały. Zgromadzenie Plenarne KRASP. 6-7.05.2010. http://www.krasp.org.pl/pl/archiwum_uchwaly_2008 _2012/u_2008_2012[10.07.2015].

KRASP. Dokument 40/VI: Uchwała w sprawie opracowania Program rozwoju szkolnictwa wyższego do 2020 r. Zgromadzenie Plenarne KRASP. 22.05.2015. http://www.krasp.org.pl/pl/ uchwaly/uchwaly_krasp [10.07.2015].

KRASP. Dokument 56/V: Uchwała w sprawie strategii rozwoju szkolnictwa wyższego. Prezydium KRASP. 8-9.12.2011. http://www.krasp.org.pl/pl/archiwum_uchwaly_2008_2012/u _2008_2012 [10.07.2015].

KRASP. Dokument 9/VI: Uchwała Prezydium KRASP z dnia 11 stycznia 2013 r. w sprawie współdziałania MNiSW-KRASP na rzecz modernizacji kraju. Apel do Parlamentu i Rządu Rzeczypospolitej Polskiej. Prezydium KRASP. 10-11.01.2013. http://www.krasp.org.pl/pl/uchwaly/ uchwaly_krasp [10.07.2015].

KRASP. Sprawozdanie z działalności Konferencji Rektorów Akademickich Szkół Polskich za rok 2014. http://www.krasp.org.pl/pl/inne_dokumenty/inne_dokumenty [10.07.2015].

Kulczycki,E.(2014).Niemakryzysu whumanistyce.Niemaniczego, WarsztatBadacza,http://ekulczycki.pl/warsztat_badacza/nie-ma-kryzysu-w-humanistyce-nie-ma-niczego/ [15.07.2015].

Kwiek, M. (2010). Transformacje uniwersytetu. Zmiany instytucjonalne i ewolucje polityki edukacyjnej w Europie. Poznań: Wyd. Naukowe UAM.

Kwiek, M. (2012). Uniwersytet jako „wspólnota badaczy”? Polska z europejskiej perspektywy porównawczej i ilościowej. Nauki i Szkolnictwo Wyższe 2(40): 71-101.

Kwiek, M. (2013). Reformy instytucji europejskiego uniwersytetu: napięcia, kolizje, wyzwania. Principia. Pisma koncepcyjne z filozofii i socjologii teoretycznej. LVII-LVIII: 247-268.

List otwarty naukowców do minister nauki i szkolnictwa wyższego w sprawie humanistyki. 17.02.2014. http://wyborcza.pl/1,76842,15472249,List_otwarty_naukowcow_do_minister _nauki_i_szkolnictwa.html [15.07.2015].

List otwarty polskich starożytników. 23.01.2014. http://www.rp.pl/artykul/1081453.html [15.07. 2015]. 
Mikołajczyk, K., Pawlaczyk, K. (2015). Jakie mają być nasze uczelnie i polska nauka? - relacja z debaty o przyszłości szkolnictwa wyższego i nauki w Polsce. E-mentor. 3(6o): 4-6.

MNiSW. List Minister Nauki i Szkolnictwa Wyższego prof. Leny Kolarskiej-Bobińskiej. https:// www.nauka.gov.pl/g2/oryginal/2014_03/7982docccf7ad9165f1b4488coc313dd.pdf [22.07. 2015].

MNiSW. Odpowiedź na postulaty Komitetu Kryzysowego Humanistyki Polskiej. 10.06.2015. http://www.nauka.gov.pl/aktualnosci-ministerstwo/odpowiedz-na-postulaty-komitetukryzysowego-humanistyki-polskiej.html [22.07.2015].

MNiSW. Stenogram 1: Przyszłość szkolnictwa wyższego w Polsce: cele, struktury, mechanizmy finansowania. http://www.nauka.gov.pl/g2/oryginal/2015_07/4123c8e1cdae613e1afo2d235 6085978.pdf [22.07.2015].

MNiSW. Stenogram 3: Ścieżki kariery akademickiej i naukowej. http://www.nauka.gov.pl/g2/ oryginal/2015_07/be65ca1a912fb3bdc16480594fc6de04.pdf [22.07.2015].

Musiał, K. (2013). Uniwersytet na miarę swego czasu. Transformacja społeczna w dobie postindustrialnej a zmiany w szkolnictwie wyższym krajów nordyckich. Gdańsk: słowo/obraz terytoria.

Muszewska, A., Niesiołowski-Spanò, Ł., Pieniądz, A. (red.) (2015). Pakt dla nauki, czyli jak nauka może stużyć spoleczeństwu. Obywatelski projekt zmian $w$ nauce i szkolnictwie wyższym $w$ Polsce. Warszawa: Obywatele Nauki.

Neave, G. (2002). The Stakeholder Perspective Historically Explored. W: J. Enders, O. Fulton (red.). Higher education in a globalising world. Dordrecht: Kluwer Academic Publisher.

Newman, F., Couturier, L., Scurry, J. (2004). The Future of Higher Education. Rhetoric, Reality, and the Risks of the Market. San Francisco: Jossey-Bass.

Niesiołowski-Spanò, Ł., Pieniądz, A. (2015). Sanacja uniwersytetu. Rzeczpospolita. 30.06.2015.

Obywatele Nauki. Marcin Zaród o debacie zorganizowanej przez MNiSW „Jakie mają być nasze uczelnie i polska nauka”. http://obywatelenauki.pl/2015/o6/marcin-zarod-o-debacie-zorganizowanej-przez-mnisw-jakie-maja-byc-nasze-uczelnie-i-polska-nauka/ [22.07.2015].

Obywatele Nauki. Subiektywne refleksje po publikacji Paktu dla Nauki i pierwszej o nim debacie. Ł. Niesiołowski- Spanò. http://obywatelenauki.pl/2015/o6/subiektywne-refleksje-popublikacji-paktu-dla-nauki-i-pierwszej-o-nim-debacie/ [22.07.2015].

Obywatele Nauki 2015. Okrągły Stół Humanistyki - sprawozdanie. http://obywatelenauki.pl/ 2014/o2/okragly-stol-humanistyki-sprawozdanie/ [22.07.2015].

Szczepański, J. (1999). Reformy, rewolucje, transformacje. Warszawa: IFiS PAN.

Ustawa z dnia 27 lipca 2005 r. Prawo o szkolnictwie wyższym, t.j. http://isip.sejm.gov.pl/DetailsServlet?id=WDU20051641365 [22.07.2015].

Woźnicki, J. (red.) (2015a). Program rozwoju szkolnictwa wyższego do 2020 r., część I: Opis prac nad Programem rozwoju szkolnictwa wyższego do 2020 r. i jego najważniejsze elementy. Warszawa: KRASP, Fundacja Rektorów Polskich.

Woźnicki, J. (red.) (2015b). Program rozwoju szkolnictwa wyższego do 2020 r., część II: Misja społeczna uniwersytetu $w$ XXI wieku. Warszawa: KRASP, Fundacja Rektorów Polskich.

Woźnicki, J. (red.) (2015c). Program rozwoju szkolnictwa wyższego do 2020 r., część V: Deregulacja w systemie szkolnictwa wyższego. Warszawa: KRASP, Fundacja Rektorów Polskich.

Zybała, A. (2013). Państwo i społeczeństwo $w$ działaniu. Polityki publiczne wobec potrzeb modernizacji państwa i społeczeństwa. Warszawa: Difin. 


\title{
Dialogue with academic stakeholders in designing the vision and reforms of higher education in Poland (2013-2015)
}

\begin{abstract}
What is particularly interesting in the relations between the state and stakeholders is the reception of the currently designed and implemented reform, which groups support it, and which groups are against, and - in the event of objections - where the bone of contention lies. Referring to the Polish reforms of higher education, this paper focuses on the discrepancies between the values upheld by the internal stakeholders (i.e. part of the Academia staff members) and those preferred by external stakeholders (i.e. the state). The paper concentrates mainly on the standpoints and activities of academic stakeholders who oppose the line of the Polish higher education reforms forced by the Ministry and/or who proposed their own vision of changes in higher education and science in the years 2013-2015, i.e. the Conference of Rectors of Academic Schools in Poland, the Citizens of Academia and the Polish Humanities Crisis Committee. The reference to the reactions of the Ministry to such actions leads to conclusions concerning the character of the social dialogue between the academic stakeholders and the Ministry, and the level of participation of the Academia in the process of reforming higher education in Poland.
\end{abstract}

KEYWORDS: higher education reform, higher education policy, university, stakeholders, social dialogue

CYTOWANIE: Dziedziczak-Foltyn, A. (2015). Dialog z interesariuszami środowiskowymi w projektowaniu wizji i reformy szkolnictwa wyższego w Polsce. Nauka i Szkolnictwo Wyższe. 1(45): 137159. DOI: 10.14746/nsw.2015.1.6. 